Gelanggang Pendidikan Jasmani Indonesia

\title{
PENGEMBANGAN MODEL PEMBELAJARAN GERAK DASAR BOLA VOLI UNTUK SISWA SDN 16 SUNGAI RAYA KABUPATEN KUBU RAYA
}

\section{Eka Supriatna}

eka.supriatna@fkip.untan.ac.id

\section{Info Artikel}

\section{Sejarah Artikel:}

Diterima: Bulan-Tahun

Disetujui: Bulan-Tahun

Dipublikasikan : Bulan-Tahun

Kata Kunci:

Model Pembelajaran, Gerak Dasar Bolavoli, Sekolah Tingkat Dasar.

\begin{abstract}
Abstrak
Tujuan dari penelitian ini untuk menemukan model-model pembelajaran bolavoli dalam bentuk modul yang sesuai dengan karakteristik siswa sekolah tingkat dasar (SD). Bentuk Desain Penelitian yang digunakan adalah pendekatan pengembangan Research And Development (R\&D) yang dikemukakan oleh Borg dan Gall. Instrumen yang digunakan dalam penelitian ini adalah kuesioner observasi penilaian dari ahli materi bolavoli, kuesioner observasi penilaian ahli media dan kuesioner keefektifan siswa. Hasil penelitian pengembangan ini adalah sebuah modul pembelajaran gerak dasar bolavoli untuk siswa SDN 16 Sungai Raya Kabupaten Kubu Raya. Berdasarkan hasil penilaian ahli materi bolavoli sebesar $85 \%$ dan ahli media sebesar $88 \%$ serta nilai uji keefektifan pada kelompok sebesar $90 \%$. Kesimpulan produk sangat valid, sehingga layak digunakan untuk pembelajaran pendidikan jasmani pada siswa sekolah tingkat dasar di SDN 16 Sungai Raya Kabupaten Kubu Raya.
\end{abstract}

\begin{abstract}
The purpose of this research is to find volleyball learning models in the form of modules that are in accordance with the characteristics of elementary school students. The form of research design used is the Research and Development $(R \& D)$ approach proposed by Borg and Gall. The instruments used in this study were an assessment observation questionnaire from volleyball material experts, a media expert assessment observation questionnaire and a student effectiveness questionnaire. The result of this development research is a basic motion learning module for volleyball for students of SDN 16 Sungai Raya, KubuRaya Regency. Based on the results of the evaluation of volleyball material experts of $84.37 \%$ and media experts of $88.33 \%$ and the effectiveness test value in the group was $87.34 \%$. The conclusion of the product is very good, so it is suitable to be used for physical education learning for elementary school students at SDN 16 Sungai Raya, Kubu Raya Regency.
\end{abstract}

(C) 2019 Universitas Negeri Malang

\section{PENDAHULUAN}

Pendidikan jasmani adalah suatu proses pembelajaran melalui aktivitas jasmani yang didesain untuk meningkatkan kebugaran jasmani, mengembangkan keterampilan motorik, pengetahuan dan perilaku hidup sehat dan aktif, sikap sportif, dan kecerdasan emosional. Pendidikan jasmani adalah proses pendidikan yang bertujuan untuk mengembangkan individu pada aktivitas fisik, olahraga, dan permainan yang memiliki tujuan untuk meningkatkan aspek motorik, sosial, dan emosional pada peserta didik (Rismayanti, 2011). Hakikatnya adalah proses interaksi antara peserta didik dengan lingkungan yang dikelola melalui aktivitas jasmani secara sistematik menuju pembentukan manusia seutuhnya. Aktivitas 
jasmani tersebut dapat diartikan sebagai peserta didik untuk meningkatkan keterampilan motorik dan fungsional. Dengan kata lain, prinsip-prinsip pembelajaran pendidikan jasmani yang dikembangkan haruslah dapat memacu pada pembentukan, pengembangan dan peningkatan kualitas kemampuan unsurunsur kognitif, afektif dan psikomotorik. Sesuai dengan makna pendidikan jasmani yaitu pendidikan melalui aktivitas fisik, maka salah satu prioritas utama tujuan yang ingin dicapai dalam penjas adalah penguasaan keterampilan motorik. Oleh sebab itu aktivitas yang diberikan hendaknya mampu membangkitkan dan memberikan kesempatan kepada anak untuk aktif dan kreatif, serta mampu menumbuh kembangkan potensi dan motorik anak. Dengan demikian, selama anak mengikuti proses belajar maupun latihan secara langsung akan dapat merangsang terpacunya suatu penguasaan keterampilan motorik pada umumnya dan keterampilan pada cabang olahraga tertentu pada khususnya. Salah satu materi olahraga yang sering diberikan dan dilaksanakan pada sekolah tingkat dasar adalah permainan bolavoli. Permainan bolavoli bagi siswa siswi tidak asing lagi karena permainan ini sudah sangat populer di masyarakat. Penyelenggaraan pendidikan jasmani di Sekolah Dasar (SD) khususnya materi permainan bolavoli harus berorientasi kepada pengenalan serta pelaksanaan berbagai macam kegiatan gerak dasar dalam kaitannya untuk pertumbuhan dan perkembangan peserta didik. Seperti yang dikemukakan Irsyada (2004) gerak dasar yang dilakukan dalam kegiatan bermain bola voli baik yang berkaitan dengan aktivitas pada saat memainkan bola maupun pada saat tanpa memainkan bola. Gerak dasar itu mencakup keterampilan lokomotor dan ketrampilan manipulatif. Sesuai dengan indikator pada materi permainan bola besar khususnya bolavoli bagi sekolah tingkat dasar, disebutkan bahwa siswa dapat mempraktikkan teknik dasar permainan bola besar dengan peraturan yang dimodifikasi untuk memupuk kerjasama dan toleransi. Kenyataan yang ada dalam proses pembelajaran permainan bola besar, khususnya permainan bolavoli belum seperti yang diharapkan, dimana materi pembelajaran belum sesuai dengan karakteristik tahapan pertumbuhan dan perkembangan siswa. Siswa sudah diberikan materi teknik dasar padahal tahap untuk pemula seharusnya dikenalkan gerak dasar baik dengan bola maupun tanpa bola. Tujuan dari pendidikan jasmani adalah mengembangkan potensi yang telah dimiliki atau memberi kesempatan kepada peserta didik agar mempunyai aspek mental, emosional, social, fisik, moral, dan kebugaran jasmani (Paturusi, 2012).

Modifikasi dipandang perlu dilakukan mengingat karakteristik siswa sekolah tingkat dasar berbeda dengan siswa sekolah menengah pertama (SMP). Variasi gerak dasar sebagai gerak yang multilateral sangat penting untuk dapat dikuasai oleh siswa sekolah tingkat dasar (SD). Sehingga ketika mereka belajar teknik dasar yang sesungguhnya tidak mengalami kesulitan karena kemampuan gerak dasarnya sudah baik. Bola yang digunakan dalam pengajaran maupun latihan adalah bola voli standar, sehingga kurang tepat digunakan untuk siswa sekolah tingkat dasar (SD). Kurangnya atau terbatasnya sarana dan prasarana pembelajaran maupun latihan seperti; bahan ajar atau modul bolavoli, serta alat peraga dan media yang menunjang dalam proses pembelajaran maupun latihan. Permainan bolavoli mini belum menjadi penerapan dalam proses pembelajaran maupun latihan, sehingga siswa mengalami kesulitan dikarenakan ketinggian net, luas nya lapangan yang tidak standar untuk siswa sekolah tingkat dasar (SD). Berdasarkan uraian tersebut dapat disimpulkan bahwa pembelajaran bolavoli untuk siswa sekolah tingkat dasar memiliki kekhususan dengan mempertimbangkan aspek karakteristik pertumbuhan dan perkembangan anak. Salah satu bentuk pengembangn pembelajaran adalah dengan membuat modul atau bahan ajar lainnya. Modul adalah salah satu bentuk bahan ajar yang dikemas sedemikian rupa yang bentukyanya dibuat semenarik mungkin dan dibuat secara utuh dan sistematis (Daryanto \& Aris Dwicahto, 2014).

Toyoda (2008) mengemukakan bahwa anak-anak usia 10 hingga 12 tahun biasanya menunjukkan karakteristik psikologis dan mental sebagai berikut: a) Mereka stabil secara emosional meskipun pertumbuhan fisiknya cepat b) Mereka mulai menunjukkan minat pada lingkungan mereka dan sering ingin belajar c) Mereka berusaha untuk mandiri dari orang tua dan guru mereka tetapi mereka juga suka menjadi bagian dari suatu kelompok d) Mereka tertarik pada kegiatan olahraga, terutama olahraga tim seperti bola voli dan sepak bola, seperti menentang olahraga individu.

Menurut Toyoda, (2000) Ketika proses pembelajaran bola voli berlangsung seorang guru penjas harus dapat mempertimbangkan kondisi - kondisi sebagai berikut : 1) memperkenalkan cara termudah untuk menguasai setiap pola permainan fundamental 2) mengurangi rasa takut bola 3) tingkatkan minat pada Bola Voli dengan memperkenalkan banyak prosedur pelatihan yang menarik 4) mencegah rasa sakit dan cedera dengan memperkenalkan prosedur pelatihan yang sesuai berdasarkan kemampuan dan pemain kondisi fisik 5) hindari secara langsung memperkenalkan beberapa pola bermain tanpa latihan untuk membiasakannya dengan bola 6) perkenalkan banyak situasi permainan awal sesegera mungkin setelah pemain menguasai passing dan serve teknik.

Ada beebrapa macam model pembelajaran ddaam bolavoli diantaranya 1) Bermain Dengan Bola Oleh Satu Pemain 2) Bermain Dengan Bola Oleh Dua Pemain 3) Pengantar Layanan (One Hand Pass 4) Pengantar Overhand Pass (Set-Up). Pengembangan model pembelajaran bolaoli di Sekolah Dasar (SD) 
sangat diperlukan untuk menunjang siswa dalam belajar. Penelitian yang dilakukan oleh Rahayu \& Firmansyah (2019) mengatakan bahwa pengembangan pembelajaran inovatif bagi guru SD mmberikan manfaat langsung kepada guru-guru khususnya dalam meningkatkan pengetahuan, keterampilan dan kesadaran menghargai proses kontruksi pengetahuan pada diri siswa. Penelitian serupa yang dilakukan oleh Suharnoko \& Firmansyah (2018) mengatakan bahwa pengembangan model pembelajaran gerak dasar melompat melalui permainan lompat cermin untuk siswa SD dapat digunakan dan disebarluaskan setelah memperoleh hasil evaluasi dari beberapa ahli. Sipayung \& Simanjuntak (2017) Mengatakan bahwa modul matematika dengan menerapkan variasi kooperatif valid digunakan dalam pembelajaran dan dapat dijadikan sebagai pertimbangan guru dalam mengajar. Mislan \& Santoso (2019) Pengembangan media dalam pembelajaran penjas sudah banyak dilakukan dan hal ini berpengaruh terhadap pembejaran penjas itu sendiri. Pengembangan modul pembelajaran tematik integratif berkarakter naionalisme dapat meningkatkan aktifitas belajar dan prestasi pada siswa sekolah dasar daerah Banyumas (Pambudhi \& Retnowati, 2017). Pengembangan model pembelajaran tatap muka berbasis buku cetak dengan menggunakan media interaktif memberikan hasil belajar yang efektif dilingkungan belajar (Akbar \& Hariyanto, 2020). Menurut Ardyanto dkk, (2016) yang menyatakan bahwa produk pengembangan instrumen pengetahuan pada mata pelajaran PJOK kelas XII yang dikemas dalam bentuk computer bassed test dapat memudahkan guru dalam melakukan proses penilaian dan siswa dapat mengetahui hasil skor hasil yang didapatkan setelah menyelesaikan tes. Hanum (2017) mengatakan bahwa guru perlu mengembangkan bahan ajar karena bertujuan untuk menunjang pencapaian kompetensi peserta didik dan pemilihan bahan ajar harus sesuai tuntutan indicator. Berdasarkan penjelasan dan hasil penelitian di atas maka penulis ingin melakukan penelitian dengan judul "Pengembangan Model Pembelajaran Gerak Dasar Bola Voli Untuk Siswa Sdn 16 Sungai Raya Kabupaten Kubu Raya”.

\section{METODE}

Metode dalam penelitian yaitu model penelitian dan pengembangan yang dikembangkan oleh Borg \& Gall (1983) yang meliputi 1) Tahap penelitian awal dan pengumpulan informasi, 2) Tahap perencanaan, 3) Mengembangan format awal produk, 4) Uji lapangan awal, 5) Revisi produk utama, 6) Uji lapangan utama, 7) Revisi produk secara operasional, 8) Uji lapangan secara operasional, 9) Revisi produk akhir, dan 10) Diseminasi dan implementasi.

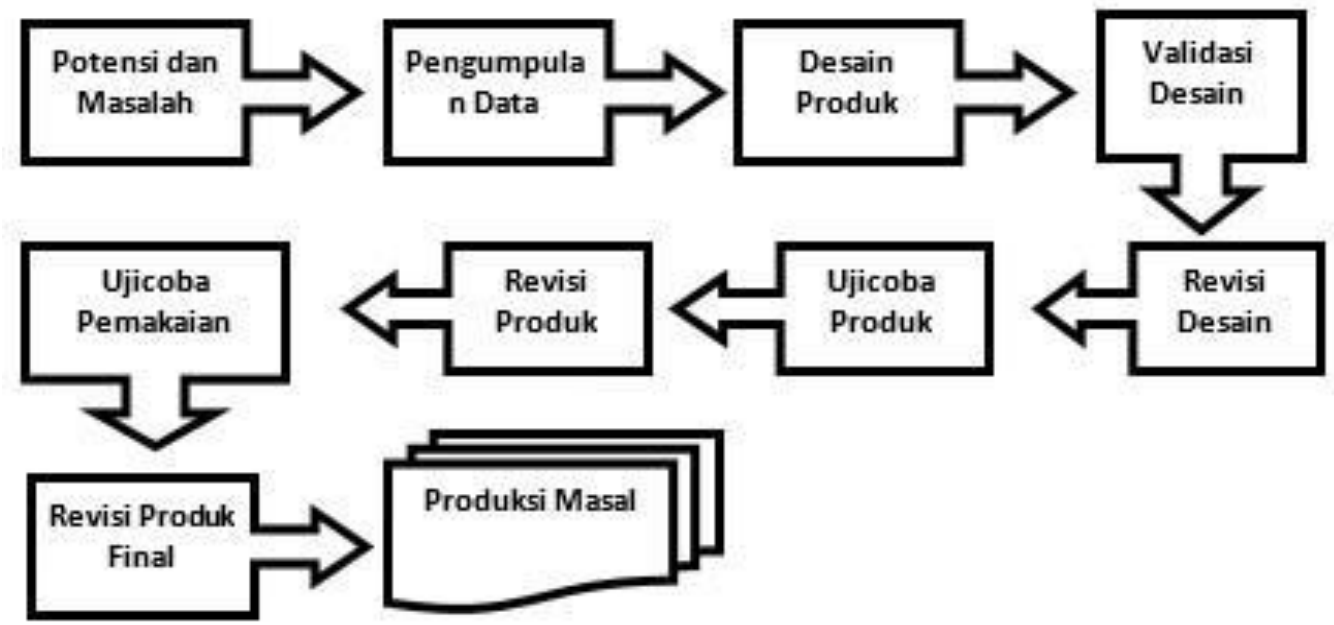

Gambar 1. Tahapan-tahapan penelitian pengembangan $R \& B$ (Sumber: (Borg \& Gall, 1983).

Penelitian dan pengembangan ini bertujuan untuk menghasilkan produk berupa modul pembelajaran gerak dasar bolavoli untuk siswa SDN 16 Sungai Raya Kabupaten Kubu Raya. Dari 10 langkah penelitian dan pengembangan dari Borg dan Gall peneliti tidak dapat melakukan semua langkah secara keseluruhan karena adanya keterbatasan-keterbatasan yang dimiliki oleh peneliti. Maka peneliti menyederhanakan langkah-langkah tersebut. 


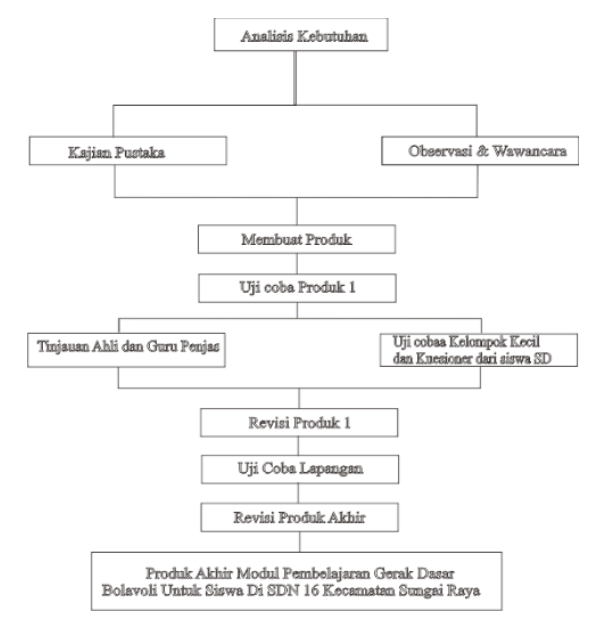

\section{Gambar 2. Prosedur Pengembangan Pembelajaran Bolavoli Untuk Siswa SD}

Pada pengembangan model pembelajaran gerak dasar bolavoli siswa sekolah tingkat dasar (SD) dilakukan melalui beberapa tahap sebagai berikut:

(1) Melakukan penelitian awal, pengumpulan data dan informasi termasuk kajian pustaka dan observasi lapangan di sekolah SDN 16 Kecamatan Sungai Raya Kabupaten Kubu Raya. (2) Mengembangkan produk awal atau rancangan produk awal. (3) Kemudian melakukan uji coba produk pada skala kelompok kecil dengan 10 siswa sebagai subyek penelitian dengan tujuan untuk mendapatkan masukan dan saran dan penilaian produk yang akan dikembangkan. (4) Merevisi hasil uji coba skala kecil dari satu ahli materi bolavoli dan ahli media serta 1 guru penjas. (5) Melakukan uji coba produk pada skala besar dengan jumlah subjek sebanyak 30 siswa. (6) Setelah melakukan uji coba skala besar dilaksanakan kemudian produk di revisi dan dievaluasi kembali oleh satu ahli materi bolavoli dan ahli media serta satu guru penjas. (7) Hasil produk akhir adalah pengembangan sebuah modul pembelajaran gerak dasar bolavoli untuk siswa SD.

Data dalam penelitian pengebangan ini mengunakan data kualitatif, dimana data yang diperoleh dinyatakan dengan deskriptif kalimat dan bukan menggunakan angka. Sedangkan data kuantitatif didapat dari hasil penskoran kuesioner. Instrumen pengumpulan data yang digunakan adalah kuesioner dimana data dalam bentuk kuantitatif yang diperoleh dari hasil pengumpulan data uji coba kelompok kecil dan uji coba kelompok besar. Teknik analisis data yang digunakan adalah uji kelayakan dan keefektifan draft modul pembelajaran gerak dasar bolavoli untuk siswa SD yang dihasilkan dengan cara penilaian ahli materi bolavoli, ahli media dan guru penjas.

Untuk mempermudah proses menyimpulkan data hasil analisis persentase dapat digolongan sesuai dengan persentase yang sudah diperoleh. Menurut Akbar \& Sriwiyana (2011) penggolongan persentase sebagai berikut:

Tabel 1.Kriteria Kualitas Produk

\begin{tabular}{cc}
\hline Skor Persentase & Kategori/Kelayakan \\
\hline $75,01 \%-100,00 \%$ & Sangat Valid \\
$50,01 \%-75,00 \%$ & Cukup Valid \\
$25,01 \%-50,00 \%$ & Tidak Valid \\
$00,00 \%-25,00 \%$ & Sangat Tidak Valid \\
\hline
\end{tabular}

\section{HASIL}

Data yang disajikan pada bahasan ini meliputi data dari: 1) validasi ahli materi bolavoli, 2) validasi ahli media pembelajaran, 3) uji coba kelompok kecil, 4) uji coba kelompok besar.

\section{Validasi Ahli Materi Bola Voli}

Tabel 2. Uji Coba Tahap I

\begin{tabular}{clccc}
\hline No. & & Aspek & \% & Kategori \\
\hline 1. & Kemenarikan & 70 & Cukup Valid \\
2. & Kepraktisan & 60 & Cukup Valid \\
3. & Keefektifan & 65 & Cukup Valid
\end{tabular}




\begin{tabular}{|c|c|c|c|}
\hline & Rata-rata & 65 & Cukup Valid \\
\hline \multicolumn{4}{|c|}{ Tabel 3. Uji Coba Tahap II } \\
\hline No. & Aspek & $\%$ & Kategori \\
\hline 1. & Kemenarikan & 90 & Sangat Valid \\
\hline 2. & Kepraktisan & 80 & Sangat Valid \\
\hline 3. & Keefektifan & 85 & Sangat Valid \\
\hline \multicolumn{2}{|r|}{ Rata-rata } & 85 & Sangat Valid \\
\hline
\end{tabular}

Hasil validasi oleh ahli materi bolavoli pada tahap uji coba tahap I menunjukkan bahwa rata-rata persentase kelayakan modul siswa sebesar $65 \%$ yang berarti modul pembelajaran gerak dasar bolavoli cukup valid dan modul pembelajaran gerak dasar bolavoli dapat digunakan dengan catatan ada revisi dari segi materi. Meski modul masuk kedalam kategori cukup layak, peneliti tetap melakukan revisi dengan memperhatikan beberapa saran yang diberikan oleh validator diantaranya: (1) Di setiap sub modul perlu disajikan standar kompetensi (SK) dan kompetensi dasar (KD) dari setiap materi. (2) Perlu ditambahkan penjelasan tujuan dari setiap model-model pembelajaran gerak dasar bolavoli. (3) Di penyajian pembelajaran khususnya gambar lebih diperjelas lagi. (4) Materi pembelajaran lebih tersusun secara sistematis lagi. Setelah direvisi dilanjutkan dengan uji coba tahap II dan hasil penilaian ahli materi menunjukan hasil yang meningkat sebesar $85 \%$, dari kriteria penilaian menunjukan bahwa modul pembelajaran gerak dasar bolavoli masuk dalam kategori sangat valid digunakan pada proses pembelajaran.

Validasi Ahli Media Pembelajaran

Tabel 4. Uji Coba Tahap I

\begin{tabular}{clcl}
\hline No. & Aspek & \% & Kategori \\
\hline 1. & Kemenarikan & 80 & Sangat Valid \\
2. & Kepraktisan & 70 & Cukup Valid \\
3. & Keefektifan & 75 & Cukup Valid \\
\hline & Rata-rata & 75 & Cukup Valid \\
\hline
\end{tabular}

Tabel 5. Uji Coba Tahap II

\begin{tabular}{clcl}
\hline No. & Aspek & \% & Kategori \\
\hline 1. & Kemenarikan & 90 & Sangat Valid \\
2. & Kepraktisan & 85 & Sangat Valid \\
3. & Keefektifan & 89 & Sangat Valid \\
\hline & Rata-rata & 88 & Sangat Valid \\
\hline
\end{tabular}

Validasi ahli media diperlukan sebagai evaluasi terhadap media modul yang dikembangkan oleh peneliti. Data yang diperoleh berupa data kuantitatif dan kualitatif melalui kuesioner yang diberikan peneliti kepada ahli media pembelajaran. Hasil validasi oleh ahli media pembelajaran menunjukkan bahwa ratarata persentase kelayakan modul pembelajaran gerak dasar bolavoli untuk siswa SDN 16 Sungai Raya Kabupaten Kubu Raya sebesar $75 \%$ yang berarti modul siswa cukup valid. Walaupun modul masuk dalam kategori cukup layak tetap peneliti merevisi dan memperhatikan saran dari validator untuk perbaikan produk modul pembelajaran gerak dasar selanjutnya, saran perbaikan dari hasil validasi ahli media yaitu : (1) Desain modul dibuat lebih menarik dan disesuaikan ukurannya. (2) Desain isi model disesuaikan dengan sistematika yang berlaku. (3) Penggunaan istilah dan simbol di dalam modul diperhatikan lagi. (4) Gambar di dalam modul lebih diperjelas lagi tingkat kecerahan serta ukuran gambar disesuaikan dengan modul. Setelah direvisi pada tahap uji coba tahap I, modul pembelajaran gerak dasar bolavoli kemudian diuji coba pada tahap II. Pada uji coba tahap II penilaian ahli media memberikan penilaian sebesar $88 \%$ ini menunjukan bahwa modul pembelajaran gerak dasar bolavoli untuk siswa SDN 16 Sungai Raya Kabupaten Kubu Raya masuk dalam kategori sangat valid untuk digunakan sebagai modul pembelajaran.

\section{Uji Kelompok Kecil}

Tabel 6. Uji Kelompok Kecil 


\begin{tabular}{clcl}
\hline No. & \multicolumn{1}{c}{ Aspek } & \% & Kategori \\
\hline 1. & Kemenarikan & 80 & Sangat Valid \\
2. & Kepraktisan & 73 & Cukup Valid \\
3. & Keefektifan & 76 & Sangat Valid \\
\hline \multicolumn{2}{c}{ Rata-rata } & 76,5 & Sangat Valid \\
\hline
\end{tabular}

Berdasarkan analisis yang telah dilakukan terhadap penilaian dari siswa SDN 16 pada uji coba kelompok kecil hasilnya adalah 76,5\%, ini menunjukan bahwa modul pembelajaran gerak dasar bolavoli sangat valid digunakan pada pembelajaran bolavoli

\section{Uji Kelompok Besar}

\begin{tabular}{clccc}
\multicolumn{4}{c}{ Tabel 7. Uji Kelompok Besar } \\
\hline No. & \multicolumn{1}{c}{ Aspek } & \% & Kategori \\
\hline 1. & Kemenarikan & 90 & Sangat Valid \\
2. & Kepraktisan & 90 & Sangat Valid \\
3. & Keefektifan & 90 & Sangat Valid \\
\hline & Rata-rata & 90 & Sangat Valid \\
\hline
\end{tabular}

Pada uji coba kelompok besar setelah mengalami revisi dan dilakukan penilaian lagi ternyata mengalami peningkatan sebesar 90\%, ini menunjukan bahwa modul pembelajaran gerak dasar bolavoli sangat valid dan menarik minat siswa sehingga proses pembelajaran lebih efektif.

\section{PEMBAHASAN}

Produk akhir dari penelitian ini adalah menghasilkan sebuah modul pembelajaran gerak dasar bolavoli khusus untuk siswa sekolah tingkat dasar. Modul adalah sebuah bahan belajar yang dirancang secara sistematik berdasarkan kurikulum tertentu dan dikemas dalam bentuk satuan pembelajaran terkecil dan memungkinkan dipelajari secara mandiri dalam satuan waktu tertentu (Purwanto dkk, 2007). Dalam modul ini berisikan tentang model-model pembelajaran gerak dasar tanpa bola dan gerak dasar dengan bola yang terbagi kedalam lima sub bagian modul yaitu : (1) Bermain dengan bola oleh satu siswa. (2) Bermain berpasangan dengan bola oleh dua siswa. (3) Model gerak dasar underhand pass. (4) Pembelajaran gerak dasar one hand pass. (5) Pembelajaran gerak dasar overhead pass (set-up). Modul ini memilii keunggulan yaitu dibuat semenarik mungkin agar bisa menarik minat baca siswa sekolah dasar. Penyaiian dalam modul ini dibuat sangat simple dan mudah untuk dipahami siswa sekolah dasar.

Kenyataan yang ada dalam proses pembelajaran permainan bola besar, khususnya permainan bolavoli pada tingkat sekolah tingkat dasar saat ini belum seperti yang diharapkan, dimana materi pembelajaran belum sesuai dengan karakteristik tahapan pertumbuhan dan perkembangan siswa. Ditambah dengan kurangnya atau terbatasnya sarana dan prasarana pembelajaran seperti; bahan ajar atau modul pembelajaran bolavoli, serta alat peraga dan media yang menunjang dalam proses pembelajaran menyebabkan hasil belajar tidak sesuai dengan yang diharapkan. Disini pentingnya sebuah modul yang baik sangat diharapkan sebagai referensi pengetahuan untuk mengembangkan kemampuan gerak lokomotor, non-lokomotor serta gerak dasar manipulatif dalam pembelajaran bolavoli belum pernah ada. Sesuai dengan pendapatnya Nasution, (2003) bahwa pembelajaran dengan menggunakan modul banyak memberi keuntungan sebagai berikut : (1) Modul memberikan umpan balik (feedback). (2) Penguasaan tuntas atau mastery. (3) Modul memiliki tujuan. (4) Modul memberikan motivasi. (5) Modul memiliki fleksibilitas. (6) Modul memiliki sifat kerjasama. (7) Pengajaran remedial.

Modul pembelajaran gerak dasar bolavoli ini dapat dijadikan sebuah media belajar yang sangat efektif, sehingga siswa memiliki daya yang cukup kuat dalam proses belajar. Berdasarkan hasil penelitian menunjukan bahwa modul pembelajaran gerak dasar bolavoli untuk siswa SDN 16 Sungai Raya Kabupaten Kubu Raya masuk dalam kategori sangat layak yaitu $88 \%$ untuk digunakan sebagai modul pembelajaran. Didukung dengan ketertarikan penilaian siswa sebesar $90 \%$ ini menunjukan bahwa modul pembelajaran gerak dasar bolavoli sangat layak dan menarik minat siswa. Dapat diartikan bahwa modul pembelajaran gerak dasar bolavoli semakin kuat diakui sebagai salah satu referensi pengetahuan untuk meningkatkan minat, motivasi dan hasil belajar pada siswa SDN 16 Sungai Raya Kabupaten Kubu Raya. Hal ini sesuai dengan pendapat Ilahiyah dkk, (2019) bahwa pengembangan pembelajaran dengan modul pada siswa kelas III Sekolah dasar mendapatkan persentase nilai rata-rata yaitu $87,75 \%$ dapat diartikan sangat layak, 
kemudian mendapatkan respon yang sangat baik dari siswa dibuktikan dengan nilai persentase sebesar $97 \%$. Kemudian diperkuat oleh penelitian yang dilakukan Yoda (2019) yang mengatakan bahwa 100\% siswa menyatakan modul penjasorkes dengan materi pembelajaran bandura dapat dengan mudah dipahami dalam melatih keterampilan gerak dan kecerdasan pada siswa kelas IV SD Laboratorium Undiksha Singaraja. Hananingsih \& Saputra (2019) Mengatakan bahwa pengembangan modul bolavoli dengan menggunakan pendekatan saintifik dalam kurikulum 2013 untuk siswa kelas XII mendapatkan rata-rata skor sebesar 80,83 dari 30 siswa dan juga dari uji coba kelompok modul ini dinyatakan menarik karena matteri disertai dengan gambar dan Langkah-langkah dengan jelas dan rata-rata nagka yang didapat juga tinggi yaitu 3,87. Penelitian yang dilakukan oleh Susanti (2017) mengatakan modul dari tigas aspek validitas (aspek materi, bahasa dan desain) diproleh rata-ratanya sebesar 92,60\%. modul yang telah dikembangkan dikategorikan sangat praktis oleh guru dengan rata-rata persentase kepraktisan 92,77\%, juga dikategorikan sangat praktis menurut siwa dengan rata-rata persentase keprakisan 91,99\%, modul pembelajaran IPS berbasis Cooperative Script pada tema 8 Daerah Tempat Tinggalku untuk kelas IV SD yang telah dikembangkan dapat digunakan sebagai salah satu alternatif bahan ajar.

Abdillah (2013) yang mengatakan bahwa pembelajaran dengan media modul dapat meningkatkan hasil belajar pada siswa sekolah dasar kelas V SDN Sarikaya Condongcatur, dibuktikan dengan nilai ratarata siswa sebelum menggunakan modul adalah 37,00 kemudian setelah menggunakan modul nilai ratarata siswa meningkat menjadi 66,20. Pengembangan pembelajaran dengan modul juga dapat meningkatkan pengetahuan dan perubahan sikap pada siswa SD Inpres IKIP I Kota Makassar hal ini dibuktikan dengan 28 responden yang sebelumnya memiliki pengetahuan kurang tentang PHBS (perilaku hidup bersih dan sehat) kemudian mengalami peningkatan pada materi tersebut setelah diberikan pengembangan berupa modul (Mallo dkk, 2019). Rachmawati dkk, (2020) mengatakan bahwa ada pengaruh yang signifikan dari modul untuk dapat meningkatkan pengetahuan siswa dalam belajar pada siswa kelas V SDN Lembah Putro 1 Sidoarjo pada pembelajaran kurikulum 2013. Purwaningtyas dkk, (2017) mengatakan bahwa pengembangan modul elektronik berbasis online dengan program etmodo dapat menjawab permasalahan minimnya bahan ajar pada mata pelajar PJOK. Pengembangan modul berbasis kurikulum 2013 sangat vali dan sangat layak digunakan dalam pembelajaran, modul ini juga efektif ditinjau dari motivasi siswa dengan rata-rata nilai 94,10, meningkatkan aktifitas belajar siswa dengan rata-rata 92 termasuk dalam kategori aktif sekali dan hasil belajar siswa dengan rata-rata 85,50 (Susanti, 2017).

Pengembangan model pembelajaran sirkuit pendidikan jasmani adaptif dapat mengembangkan pola gerak dasar untuk anak down syndrome, dengan demikian pengembangan ini sangat bermanfaat dalam membantu proses pembelajaran (Pertiwi dkk, 2018). Penelitian yang dilakukan oleh Saputro dkk, (2018) mengatakan bahwa pengembangan modul pencak silat layak untuk digunakan guru SMK dalam menyampaikan materi dan modul ini juga mempermudah siswa untuk memahami materi pencak silat. Pengembangan media pembelajaran dengan buku model pembelajaran bolavoli pada siswa SMP Negeri 1 Rogojapi banyuwangi dikatakan layak setelah melewati beberapa uji ahli dan dapat digunakan dalam pembelajaran karena didalamnya terdapat teknik pembelajaran dari mudah ke sulit disertai dengan gamegame dan peraturan (Sujito, 2020). Pengembangan model pembelajaran menggunakan modul dapat membantu proses beajar pada siswa Sekolah Dasar (SD) kelas V hal ini dibuktikn dengan meningkatnya nilai rata-rata anak pada saat pretest dan posttest, pada pretest nilai rata-rata siswa yang tuntas hanya mencapai $34,15 \%$, setelah diberikan modul pembelajaran nilai rata-rata siswa yang tuntas meningkkat menjadi 74,05\% pada saat posttest (Arum \& Wahyudi, 2016). Dari semua pembahasan di atas dapat dikatakan pengembangan media pembelajaran berbasis moduul banyak memberikan manfaat pada siswa. Hal ini karena bentuk modul itu sendiri yang dibuat menarik dan tidak membosankan, beberapa variasi gambar yang terdapat dimodul merupakan salah satu nilai menarik yang ingin diketahui siswa-siswi yang ingin belajar akan hal yayng baru.

\section{KESIMPULAN}

Berdasarkan pada hasil pengembangan modul pembelajaran gerak dasar bolavoli untuk siswa SDN 16 Sungai Raya Kabupaten Kubu Raya, dapat disimpulkan bahwa hasil pengembangan modul tersebut dapat digunakan sebagai referensi bahan pembelajaran untuk mempermudah penguasaan materi gerak dasar dalam permainan bolavoli dengan baik dan benar. Hal ini dibuktikan pada uji keompok besar mendapatkan rata-rata sebesar 90\% yang artinya sangat valid utuk digunakan dalam pembelajaran, untuk nilai kemenarikan memperoleh angka 90\% yang artinya modul ini juga sangat menarik bagi siswa, nilai efektifitas juga mendapat angka $90 \%$ yang artinya prodk ini memiliki efektifitas yang tinggi untuk membantu proses pebelajaran bola voli dan nilai kepraktisan juga mendapat angka 90\% yang artinya modul ini sangat praktis. 


\section{DAFTAR PUSTAKA}

Abdillah, F. D. (2013). Penggunaan Modul Sebagai Upaya Peningkatan Hasil Belajar Siswa Dalam Mata Pelajaran TIK Pada Materi Microsoft Word Kelas V di SDN Sarikaya Kragilan Condongcatur Sleman Yogyakarta. Jurnal Elektronik Pendidikan Teknik Informatika, 2(1).

Akbar, R. A., \& Hariyanto, E. (2020). Pengembangan Bahan Ajar Pencak silat Untuk Siswa Sekolah Dasar. Sport Science and Health, 2(7), 350-356.

Akbar, S., \& Sriwiyana, S. (2011). Pengembangan Kurikulum dan Pembelajaran Ilmu Pengetahuan (IPS). Cipta Media.

Ardyanto, E. R., Winarno, M. E., \& Adi, S. (2016). Pengembangan Instrumen Pengetahuan Mata Pelajaran Pendidikan Jasmani Olahraga Kesehatan (PJOK) Untuk Siswa Kelas Xii Sekolah Menengah Atas. Jurnal Pendidikan, 1(10), 1897-1903.

Arum, T. S., \& Wahyudi, W. (2016). Pengembangan Modul Pembelajaran Tematik Integratif Subtema Hubungan Makhluk Hidup Dalam Ekosistem Pendekatan Saintifik Untuk Kelas 5 Sd. Scholaria: Jurnal Pendidikan Dan Kebudayaan, 6(3), 239. https://doi.org/10.24246/j.scholaria.2016.v6.i3.p239-250

Borg, W. R., \& Gall, M. D. (1983). Educational Research an Introduction. Longman.

Daryanto, \& Aris Dwicahto. (2014). Pengembangan Perangkat Pembelajaran. Gave Media.

Hananingsih, W., \& Saputra, S. Y. (2019). Pengembangan Modul Permainan Bolavoli Menggunakan Pendeatan Saintifik dalam Kurikulum 2013 untuk Pendidikan Kesetaraan Paket C Kelas XII. Jurnal Ilmu Sosial Dan Pendidikan, 3(3), 50-55.

Hanum, L. (2017). Perencanaan Pembelajaran. Syiah Kuala University Press.

Ilahiyah, N., Yandari, I. A. V., \& Pamungkas, A. S. (2019). Pengembangan Modul Matematika Berbasis Pakem Pada Materi Bilangan Pecahan di SD. Terampil : Jurnal Pendidikan Dan Pembelajaran Dasar, 6(1), 49-63. https://doi.org/10.24042/terampil.v6i1.4127

Irsyada, M. (2004). Pembelajaran Bolavoli. Depdiknas.

Mallo, A., Sumira, Jaya, N., \& Djalil, N. (2019). Pengembangan Modul PHBS (Perilaku Hidup Bersih Dan Sehat) Sekolah di SD Inpres Btn Ikip I Kota Makassar. Jurnal Kebidanan Vokasioal, 4(1), 5055. https://doi.org/https://doi.org/10.35892/jkv.v4i1.225

Mislan, \& Santoso, D. A. (2019). Peran Pengembangan Media Terhadap Keberhasilan Pembelajaran PJOK di Sekolah. Prosiding Seminar Nasional IPTEK Olahraga, 12-16.

Nasution, S. (2003). Berbagai Pendekatan dalam Proses Belajar \& Mengajar. PT Bumi Aksara.

Pambudhi, T., \& Retnowati, T. H. (2017). Pengembangan Modul Pembelajaran Tematik Integratif Berkarakter Nasionalisme Kelas IV Sekolah Dasar Daerah Banyumas. Jurnal Pendidikan Karakter, 7(1), 71-85.

Paturusi, A. (2012). Manajemen Pendidikan Jasmani dan Olahraga. PT. Rineka Cipta.

Pertiwi, R. M., Nurhasan, N., \& Syam, T. A. R. (2018). Pengembangan Model Pembelajaran Sirkuit Untuk Membantu Pola Gerak Lokomotor, Non Lokomotor, dan Manipulatif Anak Down Syndrome. Jendela Olahraga, 3(2), 26-36. https://doi.org/10.26877/jo.v3i2.2452

Purwaningtyas, Dwiyogo, W. D., \& Hariadi, I. (2017). Pengembangan Modul Elektronik Mata Pelajaran Pendidikan Jasmani, OLahraga dan Kesehatan Kelas XI Berbasis Online dengan Program Etmodo. Jurnal Pendidikan, 2(1), 121-129.

Purwanto, Rahadi, A., \& Lasmono, S. (2007). Pengembangan Modul. Pusat Teknologi Informasi dan Komunikasi Pendidikan (PUSTEKKOM) Depdiknas.

Rachmawati, N., Muhyi, M., \& Wiyarno, Y. (2020). Pengembangan Permainan Olahraga Tradisional utuk Meningkatkan Nilai Peduli dalam Pembelajaran Pendidikan Jasmani Olahraga dan Kesehatan di Sekolah. Jurnal Pendidikan Kesehatan Rekreasi, 6(2), 125-137.

Rahayu, G. D. S., \& Firmansyah, D. (2019). Pengembangan Pembelajaran Inovatif Berbasis Pendampingan Bagi Guru Sekolah Dasar. Abdimas Siliwangi, 1(1), 17. https://doi.org/10.22460/as.v1i1p17-25.36

Rismayanti, C. (2011). Optimalisasi Pembentukan Karakter dan Kedisiplinan Siswa Sekolah Dasar Melalui Pendidikan Jasmani Olahraga dan Kesehatan. Pendidikan Jasmani Indonesia, 8(April), 117.

Saputro, G. E., Hanief, Y. N., Herpandika, R. P., \& Saputro, D. P. (2018). Modul tutorial sebagai media pembelajaran pencak silat untuk siswa sekolah menengah kejuruan. Jurnal Keolahragaan, 6(2), 130-138. https://doi.org/10.21831/jk.v0i0.21099

Sipayung, T. N., \& Simanjuntak, S. D. (2017). Validitas Modul Matematika Kelas X Sma Dengan Menerapkan Variasi Model Pembelajaran Kooperatif. MES: Journal of Mathematics Education and 
Science, 3(1), 30-36. https://doi.org/10.30743/mes.v3i1.217

Suharnoko, F., \& Firmansyah, G. (2018). Pengembangan Model Pembelajaran Melompat Melalui

Permainan Lompat Cermin untuk Siswa Sekolah Dasar. Jurnal SPORTIF : Jurnal Penelitian

Pembelajaran, 4(2), 145. https://doi.org/10.29407/js_unpgri.v4i2.12169

Sujito. (2020). Pengembangan model Pembelajaran Passing Bawah Bolavoli. JURNAL PENJAKORA,

$7(1), 72-78$.

Susanti, R. (2017). Pengembangan Modul Pembelajaran Berbasis Kurikulum 2013 di Kelas V SD Negeri

21 Batubasa Tanah Datar. Jurnal Manajemen, Kepemimpinan, Dan Supervisi Pendidikan, 2(2),

233-255.

Toyoda, H. (2000). Coaches Manual. Federation International Volleyball (FIVB).

Toyoda, H. (2008). Mini Volleyball. Federation International Volleyball (FIVB).

Yoda, I. K. (2019). Implemetasi Modul Penjasorkes Bermuatan Model Pembelajaran Bandura Untuk Meningkatkan Hasil Belajar Penjasorkes dan Kecerdasan Kinestetik Siswa Sekolah Dasar. JURNAL PENJAKORA, 6(2), 127-133. 